
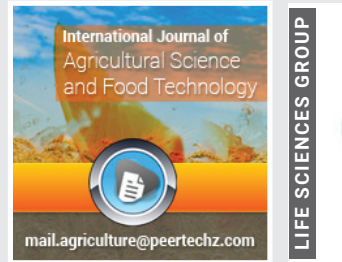

\title{
Effect of storage container and storage period on germination of grain maize in bako, West Shewa, Ethiopia
}

\author{
Negasa Fufa ${ }^{1 *}$, Solomon Abera ${ }^{2}$ and Girma Demissie ${ }^{3}$ \\ ${ }^{1}$ Ambo Agricultural Research Center, P.O. Box: 37, Ambo, Ethiopia \\ ${ }^{2}$ Department of food Science and Post-Harvest Technology, Haramaya Institute of \\ Technology, Haramaya University, P.O. Box: 138, Dire Dawa, Ethiopia \\ ${ }^{3}$ Holleta Agricultural Research Center, P.O. Box: 31, Holleta, Ethiopia
}

Received: 17 June, 2020

Accepted: 24 June, 2020

Published: 26 June, 2020

*Corresponding author: Negasa Fufa, Ambo Agricultural Research Center, P.O. Box: 37, Ambo, Ethiopia, E-mail:mergafufa@gmail.com

Keywords: Initial loading; Germination; Storage container; Hermetic, Maize

https://www.peertechz.com

Check for updates

\begin{abstract}
Grain quality is in terms of heritably and physically pure whereas postharvest managements are used to increase grain/seed quality through seed processing while required storage condition maintain its quality. However, little information available on germination capacity of maize as affected by storage containers and period in Ethiopia. Thus, the aim of the study was to evaluate the effects of storage containers with storage period on germination of maize grain in the laboratory. The experiment was conducted between December 2017 and May 2018 in Bako, West Shawa, Ethiopia. The experiment was arranged in CRD designs with three replications. The treatments consist of two factors combinations with storage types (Gombisa, sack and Hermetic bag) and storage periods $(0,1,2,3,4,5$, and 6$)$ months. Germination test was done by the standard procedures of international seed test agency (ISTA). The collected data were analyzed statistically using Generalized Linear Model (GLM) procedure of SAS and means that were significantly different were separated using Least Significant Difference (LSD). The result showed significant different $(P<0.05)$ interaction effect on germination. The values for initial loading were $98.0 \%$ and subsequently reduced $78.9 \%$ at the end of 6 months of storage. Initially, the highest $98.0 \%$ germination was recorded and reduced significantly $(\mathrm{p}<0.05)$ to $72.0,76.0$ and $88.6 \%$ for Gombisa, Sack and Hermetic bags, respectively. Hermetic bag kept significantly higher germination percentage with $94.2 \%$ at six 6 months in storage, respectively as compared to the rest of the two storage containers. The reduction of germination of grain stored in Gombisa and Sack were due to the grain damaged by weevils (S. zeamais, S. granaries, T. castaneum and S. cerealella) and increment of moisture content due to insect infestation and mould growth. From this study, it can be concluded that maize grains which was stored for less than 4 months had shown better seed germination but variations were observed among the storage structures studied. Also, Hermetic bag storage showed better result with higher germination throughout the storage periods.
\end{abstract}

\section{Introduction}

Maize is the second most widely cultivated crop in Ethiopia and is grown under diverse agro-ecologies and socioeconomic conditions typically under rain-fed production [1]. In 2013 about $6,674,048$ tons of maize grain was produced in Ethiopia [2]. These productions of maize depend on various factors. Among these; seed quality and post- harvest management are the most important. Seed quality is in terms of genetically and physically pure whereas postharvest managements are used to increase seed quality through seed processing while required storage condition maintain its quality [2]. These factors influence on the success of seed germination, normal seedling and final seed production. Nielsen [3] defined germination as the renewal of enzymatic activity that results in cell division and elongation and, ultimately, embryo emergence through the seed coat. However, germination in practical terms is the emergence of seedlings on the soil surface. Germination is triggered by absorption of water through the seed coat [3].

He also stated that the repeated wetting and drying cycles of seed maize in store can decrease seed viability and in severe cases stop germination altogether. Seed quality is judged by different end users such as farmers and industries. For instance, farmers expect to obtain high quality seeds that are able to germinate and produce normal seedlings under field conditions [4]. Seed quality of maize has the capacity to high germinate and might be contributed to high initial downward growth as 
well fast growing subsequently good seedling establishment. Among the causes of seed insecurity in Africa is inadequate facilities and inappropriate methods for seed storage among rural farmers. This impairs the maintenance of sufficient and safe seed resources compounded with poverty, and insufficient technical and financial support [5]. Successful seed storage is the main to farmers' seed security and may also enable communities to generate income through collecting, storing and selling seeds. Seed storage problems are partly responsible for farmers' failure to save seeds of non-traditional crops [6].

Poor seed storage conditions have been reported to cause up to $10 \%$ loss in seed quality in the tropics mainly through loss of viability $[7,8]$. After eight months of maize storage in the uncontrolled warehouse in South Africa, the germination declined from $87-99 \%$ to $50-80 \%$ [9]. Therefore, the objective of this study was conducted observe the effectiveness of storage containers on germination which were evaluated every 30 days after starting the experiment. They found that seed stored in gombisa had low germination after 4, 5 and 6 months respectively. Longest storability was recorded in hermetic bag with all storage container used. They concluded that grain stored in hermetic bag were superior in storability compared to those stored in gombisa and sack in maintaining the germination level.

\section{Materials and methods}

\section{Description of the study area}

This study was conducted at Bako Agricultural Research Center located in East Wollega Zone of the Oromia Regional State, western Ethiopia at an altitude of 1650 meters above sea level (m.a.s.l). Bako lies at $9{ }^{\circ} 6$ " north latitude and $370{ }^{\circ} 9$ " east longitude in the sub-humid ecology of the country 260 $\mathrm{km}$ west of Addis Ababa and $8 \mathrm{~km}$ away to the South from the main road to Nekemte. Average annual rainfall at this location is $1237 \mathrm{~mm}$. The rainy season extends from May to October and maximum rain is received in the months of July and August. Agro-ecologically, it has a warm humid climate with mean minimum, maximum and average air temperatures of 15 , 30 and $23{ }^{\circ} \mathrm{C}$ respectively. The $\mathrm{RH}$ minimum, maximum and average of the area is $(49,74.7$ and $61.85 \%)$, respectively. The major annual and perennial crops of the area include maize, sorghum, teff, noug, hot pepper, haricot bean, sweet potato, mango, banana, and sugar cane in order of importance. The study was conducted for six (6) moths starting from harvesting time in December, 2017 to May, 2018 at Bako National Maize Research Center.

\section{Experimental plan and design}

The experiment was arranged in a $3 \times 4$ factorial combination with two factors, storage types and storage period in complete randomized design with three (3) replications. Storage types have three levels i.e. Gombisa, Sack and Hermetic bag while storage period have four levels that is $(0,1,2,3,4,5$, and 6$)$ months of storage periods. Data were collected at every two months interval, including at the start of the study making up four levels for the factor storage period.

\section{Experimental materials}

The study materials were $\mathrm{BH}-661$ maize of variety harvested in December, 2017 and three types of Gombisa and Sack and Hermetic bag storage structures.

\section{Sampling methods}

A total of 90 samples of $\mathrm{BH}-661$ maize variety were collected from each of storage structures periodically starting from the beginning of the storage $(0,1,2,3,4,5$, and 6) months of storage periods. The samples were taken from the top, middle and bottom of the storage structures. The initial maize samples from each storage structures were taken as a control at the beginning of the storage. Each sample was taken by inserting the spear into the grain mass straight to the maximum depth from the top, middle and the bottom the storage.

\section{Data to be collected}

Temperature and relative humidity: The temperature and relative humdity of the internal and external environment of the storage was measured at an interval of every week by using portable digital thermo-hygrometer (Hanna, HI8564) and measurement was done in the afternoon $3.00 \mathrm{p} . \mathrm{m}$. in the day (to reduce variations) and at the time three data was taken and its average was recorded. Measurements were taken from the center, side, and top portion of the storage according to Befekadu, et al. [10].

Grain damage: The data of damage grains were obtained by the count and weighing method. Each five hundred (500g) grains were taken from initial to last storage periods and from each of the storage types and the number of damaged and undamaged grain were obtained using a hand lens by searching for the presence of hole on the seeds. The percentage of damaged grains was calculated according to the methods used by Wambugu, et al. [11] as follows:

$$
\text { DG }(\%)=\frac{\text { Munber of damaged grain }}{\text { Total number of grain samples }} \times 100
$$

Where, $\mathrm{DG}=$ percentage of damaged grain

Grain weight loss: The per cent weight loss was calculated using initial and final grain weight measurements (180 days period). Weight Loss was obtained by using the formula (Adams and Schulton, 1978). Then, the percentage weight loss was calculated as follows:

$$
\% \text { Weight Loss }=\frac{(\mathrm{UND})-(\mathrm{DNU})}{\mathrm{U}(\mathrm{ND})+\mathrm{NU})} \times 100
$$

Where, U- Weight of undamaged grains (g) NU- Number of undamaged grains (g) D- Weight of damaged grains (g) NDNumber of damaged grains $(\mathrm{g})$

Moisture content: Grain moisture content was determined by using the (AACC, 2005) standard procedures of oven dry methods. The grain was dried at a temperature of $105^{\circ} \mathrm{C}$ for three hours and after removed from the oven wait to cool in 
a dissector and then weighed. Then, the moisture content was calculated as follows: -

$$
\mathrm{MC}(\%)=\frac{\mathrm{Wi}-\mathrm{Wf}}{\mathrm{Wf}} \times 100
$$

Where, $\mathrm{Wi}$ = weight initial $\mathrm{W}_{\mathrm{f}}=$ weight final

Germination test: Germination test was carried out on the maize grain stored under Gombias, Sack and Hermetic bag. The sample was collected in every thirty (30) days intervals to assess how effective they were in maintaining the viability of the grain over the six months period (180 days). The baseline germination percentage was the initial loading sample taken. Seed germination test was done according to the standard procedures of ISTA (1994). Four hundred maize grains/sample were used. The grains were kept in petri-dish lined with filter paper moistened with about $4 \mathrm{ml}$ distilled water in six replicates (50 grains/petri-dishes) and incubated at room temperature $\left(a v .25^{\circ} \mathrm{c}\right)$ for 5 to 7 days. The germinated grains were counted visually up on appearance of radicle and/or plumule and percentage germination was calculated as follows: -

$$
\text { Germiniation }(\%)=\frac{\text { No.of germinated seeds }}{\text { Total No.of seeds planted in each petri-dish }} \times 100
$$

\section{Statistical analysis}

All the data collected were subjected to analysis of variance (ANOVA) by using the PROC GLM procedure (SAS institute, 2004) and difference among means were compared by the Least Significant Difference at $5 \%$ level of significance (Steel and Torie, 1980) [12]. The correlation parameters were examined using Pearson 's correlation coefficient using PROC CORR procedure of the SAS software (SAS Institute, 2004).

\section{Results and discussions}

\section{Environmental data of the grain storages during the sto- rage periods}

The temperature data was presented in Table 1. The initial temperature during loading the storages was $22.25{ }^{\circ} \mathrm{C}$. The temperature readings continued to increase continuously and reached 35.65, 34.15, 33.05 and $31.05{ }^{\circ} \mathrm{C}$ for Gombisa, Sack, Hermetic bag and the ambient, in the six months. Likewise, Befikadu, et al. (2014) reported the average temperature had ranged from 21.30 to $35^{\circ} \mathrm{C}$ for Gombisa and 16.55 to $28.95{ }^{\circ} \mathrm{C}$ for Sack while Marek, et al. (2018) reported average values of temperature inside of the floored warehouse is $21.9^{\circ} \mathrm{C}$ within the timeframe, with the maximum value of $32.6^{\circ} \mathrm{C}$ and minimal value of $12.6^{\circ} \mathrm{C}$.

The rises in temperature within the storages could be the impact of the surrounding environment from which the heat is transferred into the storages (Table 2). At the same time the temperature in the storage can increase due to the respiration heat coming from living beings inside. The corresponding ambient temperature increased was more than that in the storage in the early months of the storage periods. However,
Suleiman (2015) reported that carbon dioxide, moisture, and heat produced through respiration of the grain causes an increase in temperature and dry matter loss of the stored grain.

\section{Effect of storage container and period on moisture content of the grain}

The mean moisture content data of grains stored in the three types of storages for six months are given in Table 2. The initial moisture content was $10 \%$ for all storage types. The values did not change much after storage periods of one month. As time passed by the moisture contents in all three storage types decreased. For, instance the moisture content of samples in Gombisa dropped to $7.40 \%$ after two months and that of Sack reduced to $8.40 \%$ and of the Hermetic bag to $7.80 \%$. The reduction in moisture content of grains could be loss of moisture to the air in the storage through transpiration (Evaporation). In contrast, Niamketchi [13], reported that with an individual mean of 9.23 and $9.05 \%$ at the beginning (o month), the moisture contents increased significantly $(\mathrm{P}<0.001)$ during the storage period. In the third months the moisture content of grains in Gombisa increased to $8.36 \%$ whereas those in Sack and Hermetic bag continued to drop to 8.00 and $7.50 \%$, respectively. The reduction in moisture content of grains could be loss of moisture to the air in the storage through transpiration (Evaporation). The moisture content of the grains at and after the fourth months showed

Table 1: Mean of grain and ambient temperature of stored maize over storage periods.

\begin{tabular}{|c|c|c|c|c|}
\hline \multirow{2}{*}{$\begin{array}{c}\text { Storage period } \\
\text { (months) }\end{array}$} & \multicolumn{3}{|c|}{ Mean of temperature $\left({ }^{\circ} \mathbf{C}\right)$} & $\begin{array}{c}\text { Mean of ambient } \\
\text { temperature }\left({ }^{\circ} \mathbf{C}\right)\end{array}$ \\
\cline { 2 - 5 } & Gombisa & Sack & $\begin{array}{c}\text { Hermetic } \\
\text { bag }\end{array}$ & \\
\hline ILD ILD & $22.25^{\mathrm{f}}$ & $22.25^{\mathrm{f}}$ & $22.25^{\mathrm{b}}$ & $22.25 \mathrm{e}$ \\
\hline 1 & $23.15^{\mathrm{f}}$ & $23.10^{\mathrm{f}}$ & $22.40^{\mathrm{b}}$ & $25.0 \mathrm{~d}$ \\
\hline 2 & $24.95^{\mathrm{e}}$ & $25.00^{\mathrm{e}}$ & $24.15^{\mathrm{b}}$ & $27.0 \mathrm{c}$ \\
\hline 3 & $27.30^{\mathrm{d}}$ & $26.85^{\mathrm{d}}$ & $26.20^{\mathrm{b}}$ & $28.0 \mathrm{~b}$ \\
\hline 4 & $28.95^{\mathrm{c}}$ & $28.00^{\mathrm{c}}$ & $27.85^{\mathrm{b}}$ & $29.5 \mathrm{~b}$ \\
\hline 5 & $32.80^{\mathrm{b}}$ & $30.85^{\mathrm{b}}$ & $29.55^{\mathrm{b}}$ & $31.0 \mathrm{a}$ \\
\hline 6 & $35.65^{\mathrm{a}}$ & $34.15^{\mathrm{a}}$ & $33.05^{\mathrm{a}}$ & $31.05 \mathrm{a}$ \\
\hline LSD (5\%) & 0.9 & 1 & $0.6^{\mathrm{a}}$ & 0.8 \\
\hline CV (\%) & 3.5 & 4.8 & $2.7^{\circ}$ & 4.8 \\
\hline
\end{tabular}

Note: Mean values \pm standard deviation of three replicates within each column sharing similar letters were not significantly different by LSD test at $P \leq 0.05, C V$ : coefficient of variation, LSD: least significant different, ILD: initial loading date.

Table 2: Effect of storage container and period on moisture content.

\begin{tabular}{|c|c|c|c|}
\hline \multirow{2}{*}{ Storage Period (Months) } & \multicolumn{3}{|c|}{ Mean of grain moisture content (\% db) } \\
\cline { 2 - 4 } & Gombisa & Sack & Hermetic \\
\hline ILD & $10.00 \pm 0.7^{\mathrm{c}}$ & $10.00 \pm 0.52^{\mathrm{c}}$ & $10.0 \pm 0.32^{\mathrm{c}}$ \\
\hline 1 & $9.93 \pm 0.71^{\mathrm{c}}$ & $10.00 \pm 0.52^{\mathrm{c}}$ & $9.30 \pm 0.13^{\mathrm{c}}$ \\
\hline 2 & $7.40 \pm 0.14^{\mathrm{d}}$ & $8.40 \pm 0.21^{\mathrm{d}}$ & $7.80 \pm 0.12^{\mathrm{d}}$ \\
\hline 3 & $8.36 \pm 0.23^{\mathrm{d}}$ & $8.00 \pm 0.21^{\mathrm{d}}$ & $7.50 \pm 0.11^{\mathrm{d}}$ \\
\hline 4 & $10.50 \pm 0.29^{\mathrm{c}}$ & $10.20 \pm 0.26^{\mathrm{c}}$ & $9.86 \pm 0.18^{\mathrm{c}}$ \\
\hline 5 & $11.23 \pm 0.29^{\mathrm{b}}$ & $10.46 \pm 0.26^{\mathrm{c}}$ & $10.03 \pm 0.22^{\mathrm{c}}$ \\
\hline 6 & $13.9 \pm 0.29^{\mathrm{a}}$ & $11.70 \pm 0.20^{\mathrm{b}}$ & $10.70 \pm 0.24^{\mathrm{c}}$ \\
\hline LSD (5\%) & 0.53 & 0.48 & 0.72 \\
\hline CV (\%) & 3.4 & 2.3 & 2.81 \\
\hline
\end{tabular}

Note: Mean values \pm standard deviation of three replicates within each column sharing similar letters were not significantly different by $L S D$ test at $P \leq 0.05, C V$ : coefficient of variation, LSD: least significant different, ILD: initial loading date.

Citation: Fufa N, Abera S, Demissie G (2020) Effect of storage container and storage period on germination of grain maize in bako, West Shewa, Ethiopia. Int J Agric Sc Food Technol 6(1): 088-092. DOI: https://dx.doi.org/10.17352/2455-815X.000060 
continued increment reach $13.9,11.7$ and $10.70 \%$ at the end of six months storage periods for samples in Gombisa, Sack and Hermetic bag, respectively. These increments could be due to the moisture generated during respiration of the grain and other living things in the storages.

\section{Effect of storage container with storage period on grain damaged and weight loss}

The main and interaction effects of the storage containers and periods on the germination percentage was given in Tables 3,4. From initially loading the first two months of storage periods no grain damaged were recorded and significantly $(\mathrm{p}<0.05)$ increased to $0.9,2.7,4.4$ and $9.1 \%$ at $3^{\text {rd }}, 4^{\text {th }}, 5^{\text {th }}$ and $6^{\text {th }}$ months of storage. The values after the $3^{\text {rd }}, 4^{\text {th }}, 5^{\text {th }}$ and $6^{\text {th }}$ months were $1.10,2.90,5.30$ and $12.3 \%$ for Gombisa, 1.00 , 2.7, 4.1 and 9.3\% for Sack, 0.6, 2.6, 3.7 and 5.7\% for Hermetic bag, respectively. There were significantly different $(\mathrm{p}<0.05)$ high $12.3 \%$ followed by sack $9.3 \%$ and hermetic bag $5.7 \%$, respectively. Likewise, Befikadu, et al. [10], reported 11.50 and $10.75 \%$ percentage of kernel damage for Gombisa and Sack

Table 3: Interaction effect of storage container with storage on damaged grain and germination.

\begin{tabular}{c|c|c|c|c|c|c|}
$\begin{array}{c}\text { Storage } \\
\text { Period } \\
\text { (Months) }\end{array}$ & \multicolumn{3}{|c|}{ Damaged Grain (\%) } & \multicolumn{3}{c|}{ Germination (\%) } \\
\cline { 2 - 8 } & Gombisa & Sack & Hermetic & Gombisa & Sack & Hermetic \\
\hline ILD & - & - & - & $98.0 \pm 0.00^{\mathrm{a}}$ & $98.0 \pm 0.00^{\mathrm{a}}$ & $98.0 \pm 0.00^{\mathrm{a}}$ \\
\hline 1 & - & - & - & $98.0 \pm 0.00^{\mathrm{a}}$ & $98.0 \pm 0.00^{\mathrm{a}}$ & $98.0 \pm 0.00^{\mathrm{a}}$ \\
\hline 2 & - & - & - & $96.0 \pm 2.00^{\mathrm{b}}$ & $96.0 \pm 1.15^{\mathrm{b}}$ & $98.0 \pm 2.00^{\mathrm{a}}$ \\
\hline 3 & $1.10 \pm 0.00^{\mathrm{g}}$ & $1.00 \pm 0.00^{\mathrm{g}}$ & $0.6 \pm 0.00^{\mathrm{h}}$ & $90.0 \pm 2.00^{\mathrm{d}}$ & $93.3 \pm 1.15^{\mathrm{c}}$ & $96.0 \pm 2.00^{\mathrm{b}}$ \\
\hline 4 & $2.9 \pm 0.58^{\mathrm{f}}$ & $2.7 \pm 0.62^{\mathrm{f}}$ & $2.6 \pm 0.00^{\mathrm{f}}$ & $86.6 \pm 2.00^{\mathrm{f}}$ & $88.7 \pm 3.06^{\mathrm{e}}$ & $94.0 \pm 2.00^{\mathrm{c}}$ \\
\hline 5 & $5.3 \pm 0.58^{\mathrm{c}}$ & $4.1 \pm 0.47^{\mathrm{d}}$ & $3.7 \pm 0.44^{\mathrm{e}}$ & $76.7 \pm 2.00^{\mathrm{h}}$ & $84.0 \pm 3.06^{\mathrm{g}}$ & $90.7 \pm 2.31^{\mathrm{d}}$ \\
\hline 6 & $12.3 \pm 0.58^{\mathrm{a}}$ & $9.3 \pm 0.47^{\mathrm{b}}$ & $5.7 \pm 0.44^{\mathrm{c}}$ & $72.0 \pm 2.00^{\mathrm{i}}$ & $76.0 \pm 2.00^{\mathrm{h}}$ & $88.6 \pm 2.31^{\mathrm{e}}$ \\
\hline LSD (5\%) & & 0.39 & & & 1.6 & \\
\hline CV (\%) & & 8.6 & & & 7 & \\
\hline
\end{tabular}

Note: Mean values \pm standard deviation of three replicates within each column sharing similar letters were not significantly different by $L S D$ test at $P \leq 0.05, C V$ : coefficient of variation, LSD: least significant different, ILD: initial loading date.

Table 4: Main effect of storage container with period on grain damage, germination and weight loss.

\begin{tabular}{|c|c|c|c|}
\hline $\begin{array}{l}\text { Storage periods } \\
\text { (months) }\end{array}$ & Grain damaged (\%) & Weight loss (\%) & Germination (\%) \\
\hline ILD & - & - & $98.0 \pm 2.02^{\mathrm{a}}$ \\
\hline 2 & - & - & $96.7 \pm 2.37^{\mathrm{b}}$ \\
\hline 3 & $0.90 \pm 0.00^{d}$ & $1.20 \pm 0.00^{d}$ & $93.1 \pm 2.45^{c}$ \\
\hline 4 & $2.7 \pm 1.08^{c}$ & $3.1 \pm 1.06^{c}$ & $89.8 \pm 2.32^{d}$ \\
\hline 5 & $4.4 \pm 1.30^{b}$ & $5.3 \pm 1.30^{b}$ & $83.8 \pm 2.20^{e}$ \\
\hline 6 & $9.1 \pm 1.72^{\text {a }}$ & $9.7 \pm 1.51^{\mathrm{a}}$ & $78.9 \pm 1.79^{f}$ \\
\hline LSD (5\%) & 0.55 & 0.51 & 1.6 \\
\hline \multicolumn{4}{|c|}{ Storage container } \\
\hline Gombisa & $3.6 \pm 1.35^{\mathrm{a}}$ & $4.4 \pm 1.00^{\mathrm{a}}$ & $86.6 \pm 1.35^{c}$ \\
\hline Sack & $3.3 \pm 1.15^{b}$ & $2.8 \pm 0.16^{b}$ & $89.3 \pm 1.94^{b}$ \\
\hline Hermetic & $2.1 \pm 0.67^{c}$ & $1.96 \pm 0.08^{c}$ & $94.2 \pm 1.79^{a}$ \\
\hline LSD (5\%) & 0.39 & 0.36 & 1.1 \\
\hline CV (\%) & 20.2 & 16.6 & 1.9 \\
\hline
\end{tabular}

Note: Mean values \pm standard deviation of three replicates within each column sharing similar letters were not significantly different by $L S D$ test at $P \leq 0.05, C V$ : coefficient of variation, LSD: least significant different, ILD: initial loading date respectively after 60 days of storage. Similarly, Waktole and Amsalu [14], reported that mean grain damage and weight losses caused by the pests under traditional storage practices were 64.50 and $58.85 \%$, respectively.

Storage container also made significant $(\mathrm{P}<0.05)$ different in weight loss with records of $4.4,2.8$, and $1.96 \%$ for those stored in Gombisa, Sack and Hermetic bag, respectively. Likewise, Deepak and Prasanta [15], also estimated 0.2 to $11.8 \%$ weight loss due to insect infestation in maize after 6 months of storage in traditional granaries in Togo. However, Stephen [16], reported average weight loss of 3.2, 4.8, 6.8, 7.2 and 8.2\% for PICS bag, barns, mud silo, polypropylene bag and jute sack, respectively. Similarly, Waktole and Amsalu [14], reported that mean percentage grain damage and weight losses caused by the pests under traditional storage practices were 64.50 and $58.85 \%$, respectively.

\section{Effect of storage container with storage period on ger- mination percentage}

The effects of the storage containers on the germination percentage of maize grains stored for 180 days were presented in Table $3 \& 4$. There were significant different $(\mathrm{P}<0.05)$ among the storage containers throughout the storage periods. Also, there were highly significant differences $(P \leq 0.01)$ among the storage periods. The highest $98.0 \%$ germination percentage was recorded at the initial month of the storage period. For storage period, at 4, 5 and 6 months the values for germination percentage were $89.8,83.8$ and $78.9 \%$, respectively. The highest value $94.2 \%$ of germination percentage was recorded in Hermetic bag followed by sack $89.3 \%$ and gombisa $86.6 \%$, respectively. Highest $98.0 \%$ of germination percentage was recorded during the initial one month of storage.

At two months of storage the germination percentage started to reduce to $96.0 \%$ for gombisa and sack and in hermetic bag it was not significantly differences $(P<0.05)$ showed reduction. The germination percentage values for grains stored in Gombisa were $98.0 \%$ in the initial and significantly dropped to $72.0 \%$ up to the $6^{\text {th }}$ months. Similarly, for the Sack, the value was $98.0 \%$ and dropped to $76.0 \%$ and for Hermetic bag $98.0 \%$ and dropped to $88.6 \%$, respectively. However, Kaleta and Górnicki [17-19], data revealed that the germination percentage decreased during the storage period, and decreased as the moisture content increased. With $18 \%$ moisture content and above the germination percentage decreased to zero after 35 days of storage. Similarly, Befikadu, et al. [10] reported germination loss of grain stored in Gombisa and Sack increased might be due to destruction of seed by weevil (Sitophilus species) and Angoumois gran moth (S. cerealella).

\section{Conclusion}

Maize grains which was stored for less than four to six months had shown better seed germination but variations were observed among the storage types studied. As grain stored for longer period, the tested maize grains were showed low germination, decreased germination rate was observed. Grain temperature, moisture content, weight loss and damaged grains showed an increasing pattern with prolonged storage.

Citation: Fufa N, Abera S, Demissie G (2020) Effect of storage container and storage period on germination of grain maize in bako, West Shewa, Ethiopia. Int J Agric Sc Food Technol 6(1): 088-092. DOI: https://dx.doi.org/10.17352/2455-815X.000060 
Therefore, this directly influences the grains quality, which the farmers requirement quality of grains that permit to germinate and homogeneousness of the seedlings stands. Grains stored in hermetic bag storage container was ideal for maize grains to maintain maximum viability for higher germination percentage.

\section{Acknowledgments}

We would like to thank Mekdes Kebede and Geta Gelana for their assistance during seed germination test and data collection

\section{References}

1. Tsedeke A, Bekele S, Abebe M, Dagne W, Yilma K, et al. (2015) Factors that transformed maize productivity in Ethiopia: Food security 7: 965-981. Link: https://bit.ly/31b72cs

2. Belay G, Temesgen C, Tolera K, Yirgalem D (2017) Effect of Storage Period on Seed Germination of Different Maize Parental Lines: Journal of Natural Sciences Research 7. Link: https://bit.ly/2VdQZad

3. Nielsen RL (2010) The Emergence Process in Corn. Corny News Network.

4. Khan N, Kazmi RH, Willems LAJ, Heusden AW, van Ligterink, W, et al. (2012) Exploring the natural variation for seedling traits and their link with seed dimensions in tomato. Plant Cell Environment 35: 929-951. Link: https://bit. ly/3eHDojb

5. Gari JA (2004) Agro-biodiversity strategies to Combat Food Security and HIV/ AIDS Impact in Rural Africa: Advancing grassroots responses for nutrition, health and sustainable livelihoods: FAO Population and Development Service, Rome, Italy.

6. Delouche JC (1982) Seed quality guidelines for the small farmer: Improved seed for the small farmer. Conference proceedings: CIAT (Centro Internacional de Agricultura Tropical), Cali, Colombia 26-29.

7. Louwaars NP (1994) Integrated Seed Supply: a flexible approach. In. Hanson J. (ed). Seed production by smallholder farmers: Proceedings of the ILCA ICARDA Research Planning Workshop held in ILCA, Addis Ababa, Ethiopia 58.

8. Gwinner J, Harnisch R, Mueck O (1991) Manual of handling and. Conservation of seeds after harvest. GTZ, Eschborn, Germany.
9. Tekrony DM, Shande T, Rucker M, Egli DB (2005) Effect of seed shape on corn germination and vigour during warehouse and controlled environmental storage. Seed Science and Technology 33: 185-197. Link: https://bit.ly/3hZjVwn

10. Befikadu D, Waktole S, Solomon A, Geremew B, Sethu MR (2012) Influence of Agro-ecologies, Traditional Storage Containers and Major Insect Pests on Stored Maize (Zea mays L.) in Selected Woredas of Jimma Zone: Asian Journal of Plant Sciences 11: 226-234. Link: https://bit.ly/2Z3As9Q

11. Wambugu PW, Mathenge PW, Auma EO, Rheenen HA (2009) Efficacy of traditional maize (Zea mays L.) seed storage methods in Western Kenya African Journal of Food Agriculture Nutrition and Development 9: 1110- 1128. Link: https://bit.ly/37X5jsu

12. Steel RGD, Torrie JH (1980) Principles and Procedures of Statistics. 2nd Ed New York: McGraw-Hill. Link: https://bit.ly/2VfSx3h

13. Niamketchi L, Chatigre O, Konan Y, Biego H (2016) Nutritive compounds evolution of postharvest maize (Zea mays L.) stored in granaries with bio-pesticides from rural conditions in Côte d'Ivoire. International Journal of Innovative Research in Technology and Science 4: 50-64. Link: https://bit.ly/2Vgr95n

14. Waktole S, Amsalu A (2012) Storage pests of maize and their status in Jimma Zone, Ethiopia. African Journal of Agricultural Research 7: 4056-4060. Link: https://bit.ly/37XCts5

15. Deepak K, Prasanta K (2017) Reducing Postharvest Losses during Storage of Grain Crops to Strengthen Food Security in Developing Countries. Foods 6: 8. Link: https://bit.ly/2Z2QIYF

16. Stephen NJ (2014) Evaluation of Farmers Storage Structures and Their Effects on The Quality of Sorghum Grain in Wa West District in The Upper West Region of Ghana. Link: https://bit.ly/3dygwB4

17. Kaleta A Górnicki K (2013) Criteria of Determination of Safe Grain Storage Time -A Review, Dordrecht, the Netherlands.

18. Abass AB, Ndunguru G, Mamiro P, Alenkhe B, Mlingi N et al. (2014) Postharvest food losses in a maize-based farming system of semi-arid savannah area of Tanzania. Journal Stored Product Research 57: 49-57. Link: https://bit.ly/2V8BcJF

19. Suleiman RA, Rosentrater KA (2015) Current maize production, postharvest losses and the risk of mycotoxins contamination in Tanzania: Agricultural and Bio Systems Engineering. lowa State University: ASABE Annual International Meeting. Link: https://bit.ly/3drUZKb

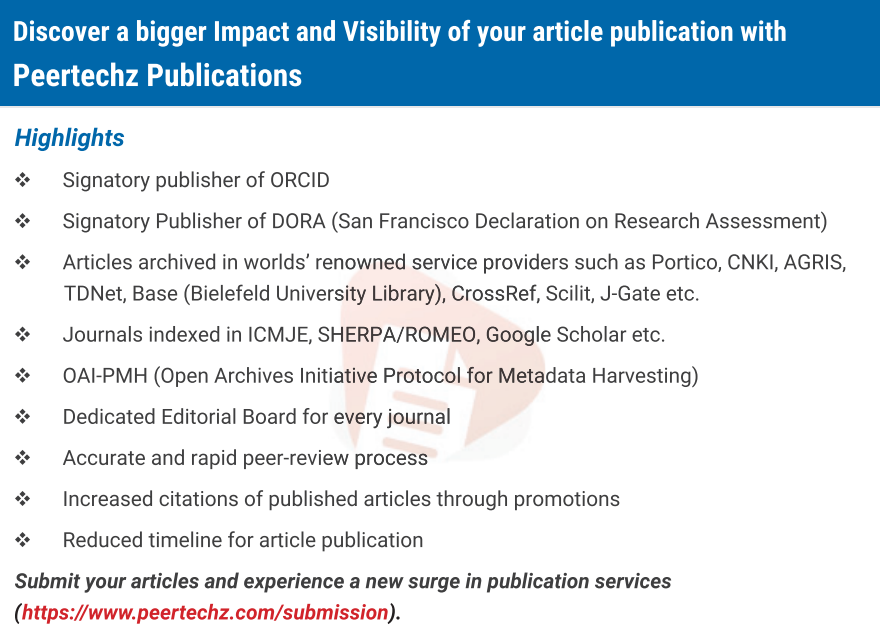

Peertechz journals wishes everlasting success in your every endeavours

Copyright: ( 2020 Fufa N, et al. This is an open-access article distributed under the terms of the Creative Commons Attribution License, which permits unrestricted use distribution, and reproduction in any medium, provided the original author and source are credited.

Citation: Fufa N, Abera S, Demissie G (2020) Effect of storage container and storage period on germination of grain maize in bako, West Shewa, Ethiopia. Int J Agric Sc Food Technol 6(1): 088-092. DOI: https://dx.doi.org/10.17352/2455-815X.000060 